\title{
A BUILDER'S OBSERVATIONS AND VIEWS AT GREYMOUTH
}

\author{
J. E. Williams*
}

\section{Introduction}

From my observations of earthquake damage in Greymouth, the main contributing cause was the age of the buildings, the lack of maintenance and poor sub-soil on which many buildings have been erected. Over the years there appears to have been little or no thought to appropriate building design, or to rectifying the position in which the area now finds itself.

It is my considered opinion that many of the buildings have reached the end of their useful life. The time has come when some authority must face up to the responsibility of determining the life span of a building and more especially the Iife span of chimneys which suffered extensive damage from this earthquake. I would venture to say that a large proportion of the damage ariaing from this earthquake and the subsequent after shocks, would have been less severe with buildings in the area being maintained to a reasonable standard.

Some earthquake repair work that I had seen leaves a lot to be desired. I would be interested to know where responsibility would lie if a further earthquake should hit Greymouth and there was $10 s 8$ of life which could in some way be attributed to the manner in which reinstatement has been carried out following this earthquake. It must be brought home to the local authority, or to the powers that be, that a good standard of repair should be maintained. Much of the damage I saw in Greymouth was not the direct result of the earthquake of the 24th May and the after shocks. Damage arising from earlier earthquakes had not been adequately repaired and in my opinion had merely been patched. I feel that the time has come when radical changes are needed and we must face up to the fact that in some areas a good standard is maintained while other areas are permitted to carry on haphazardly.

The business area is a good example of what has taken place over the years, with a maze of buildings originally constructed of corrugated iron and timber, then, as progress continued from one era to the next, face lifts were given to these buildings with no thoughtwhatsoever as to the soundness or safety of the pre-existing structure.

\section{Organization in a disaster}

I feel that in any future disaster such as experienced on the West Coast, a more realistic approach should be made in carrying out essential repair work. Local builders have done a good job within the limits of the labour force available, but I feel that organization of repair work on a zone or area basis would be more effective, but in an area such as the West Coast this would entail conscripting labour into the area. It would also necessitate strict control in the supply and distribution of essential materials and the control of the price of materials and the cost of labour. It was apparent to me that there was a big discrepancy. in the charges for certain repair work carried out on the West Coast compared with other parts of New Zealand. This may have been brought about by lack of plant and the inexperience of tradesmen in certain $t$ ypes of work.

\section{Conclusion}

From my observations on the West Coast the natural wealth of the area in coal, timber and gold has been exploited to the utmost for the benefit and progress of most of New Zealand, with very little being put back into the West Cosst. This has had a great bearing on the progress of the area.

* President, South Canterbury Master Builders' Association. 